\title{
Karakterisasi Limbah Cair Greywater pada level Rumah Tangga Berdasarkan Sumber Emisi
}

\author{
Greywater Characterization at Household Scale by Emission Source
}

\author{
Siti Nurul Khotimah ${ }^{1, *}$, Nur Anisa Mardhotillah ${ }^{2}$, Nur Arifaini ${ }^{1}$, Sumiharni ${ }^{1}$ \\ 1 Teknik Sipil, Universitas Lampung, Jl. Sumantri Brojonegoro No 1, Kota Bandar Lampung, Indonesia \\ ${ }_{2}^{2}$ PT Bina Buana Raya, Jl. Jati No 7, Kelurahan Tanjung Raya, Kecamatan Kedamaian, Bandar Lampung, Indonesia
}

\author{
* Penulis korespondensi: siti.nurul@eng.unila.ac.id \\ Tel.: +62-821-850-18853 \\ Diterima: 16 Oktober 2021; Direvisi: 29 Oktober 2021; Disetujui: 29 Oktober 2021 \\ DOI: 10.25299/saintis2021.vol21(02).7876
}

\section{Abstrak}

Limbah cair greywater merupakan limbah cair hasil aktivitas dapur, pencucian pakaian dan kamar mandi. Produksi limbah greywater rumah tangga sekitar 70-75\% dari total produksi limbah cair rumah tangga dengan kandungan polutan yang rendah. Terkait dengan tingginya volume produksi limbah cair greywater, limbah greywater berkontribusi sekitar 70-80\% dalam pencemaran badan air. Namun demikian, volume produksi limbah greywater yang tinggi ini justru dapat dijadikan sumber alternatif baru air bersih jika dilakukan pengolahan limbah dengan baik dan tepat. Di dalam pengolahan limbah greywater ini dibutuhkan data karakteristik agar pengolahanya menjadi tepat. Permasalahannya ketersediaan data karakteristik greywater sangat minim, karena itulah dilakukan penelitian ini. Penelitian ini bertujuan untuk melakukan karakterisasi limbah cair greywater berdasarkan sumber emisinya dengan parameter yang dilihat adalah BOD, COD, TSS, DO, temperature, $\mathrm{pH}$ dan turbidity dari masing-masing sumber limbah cair greywater dan juga kondisi limbah yang sudah tercampur dari ketiga sumber limbah. Penelitian dilakukan dengan mengambil sampel sebanyak 12 sampel dari suatu rumah tangga. Dari hasil penelitian menunjukan bahwa limbah dapur merupakan limbah dengan kandungan yang terberat dibandingkan limbah lainnya dari greywater. Kandungan BOD dan COD Dapur menduduki nilai tertinggi dengan nilai 250-1000 mg/L untuk BOD dan 840-3430 mg/L untuk COD. Kandungan BOD dan COD limbah greywater terendah berasal dari limbah kamar mandi dengan kandungan BOD 6-100 mg/L sedangkan kandungan COD 19,4-143 mg/L. Keseluruhan rasio BOD/COD menunjukkan nilai berkisar 0,2-0,5 yang artinya limbah adalah biodegradable. Kadar pH dari keduabelas sampel berkisar dari 4,2-6,5. Kandungan TSS tertinggi berasal dari dapur dengan nilai $202-620 \mathrm{mg} / \mathrm{L}$.

Kata Kunci: greywater, karakteristik, sumber emisi

\begin{abstract}
Greywater is wastewater generated from kitchen, laundry and bath activities. Its production is about 70-75\% of the total household wastewater. Related to the high volume of greywater production, greywater contributes around $70-80 \%$ in polluting water bodies. By appropriate treatment, the high volume of greywater production can be used as a new alternative of water source. Unfortunately, the availability of greywater characteristic data is very limited in existence. This study aims to characterize greywater effluent based on its emission source with focus parameters were BOD, COD, TSS, DO, temperature, $p H$ and turbidity from each source of greywater effluent and also the mixed waste conditions from the three waste sources. The study was conducted by taking 12 samples from a household. The results of the study show that kitchen waste is the heaviest pollutant content compared to other waste from greywater. The content of BOD and COD in the kitchen occupies the highest value with a value of 250-1000 mg/L for BOD and 840-3430 mg/L for COD. The lowest BOD and COD content of greywater came from bathroom waste with a BOD content of 6-100 mg/L while the COD content was 19.4-143 mg/L. The overall $B O D / C O D$ ratio shows a value ranging from 0.2 to 0.5 , which means that the waste is biodegradable. The $p H$ levels of the twelve samples ranged from 4.2-6.5. The highest TSS content comes from the kitchen with a value of $202-620 \mathrm{mg} / \mathrm{L}$.
\end{abstract}

Keywords: Greywater, characterization, emission sources

\section{PENDAHULUAN}

Limbah cair rumah tangga terdiri dari limbah cair greywater dan limbah cair blackwater. Limbah cair blackwater merupakan limbah cair dari toilet dalam bentuk pembuangan tinja, sedangkan limbah cair greywater merupakan limbah cair hasil aktivitas dapur, pencucian pakaian dan kamar mandi [1], [2]. Beberapa studi menunjukkan bahwa produksi dari greywater rumah tangga sekitar 70-
$75 \%$ dari total produksi limbah cair rumah tangga dengan konsentrasi yang condong lebih kecil dari keseluruhan total pollutan [3], [4], [5], [6].

Karena volume produksinya yang tinggi, limbah cair greywater merupakan limbah terbesar yang masuk ke badan air seperti sungai. Hampir di seluruh wilayah di Indonesia, limbah cair greywater masuk ke badan sungai tanpa adanya pengolahan terlebih dahulu dan ini menyebabkan kontaminasi air. Berdasarkan hasil penelitian terdahulu 
menunjukkan bahwa aktivitas domestik berkontribusi sekitar 70-80\% dalam pencemaran badan air [7].

Sebenarnya permasalahan pencemaran badan air oleh limbah cair greywater dapat diatasi dengan adanya pengolahan limbah cair sebelum dibuang ke badan air. Trend penelitian terbaru menunjukkan, bahwa selain perlu adanya pengolahan greywater untuk mengurangi pencemaran air, pengolahan limbah cair greywater dapat dijadikan sumber alternatif baru sumber air bersih [8], [9], yaitu dengan konsep penggunaan kembali (reuse) dari limbah cair greywater. Penggunaan kembali limbah cair greywater memang untuk saat ini masih terbatas seperti untuk flash toilet, irigasi tanaman, mencuci mobil, dan mencuci jendela karena kualitas air bersihnya masih rendah. Namun demikian, penggunaan kembali limbah cair greywater dapat membantu mengurangi penggunaan sumber air bersih yang tersedia sehingga dapat menjadi solusi bagi wilayah kering yang terdampak karena perubahan iklim yang ekstrim [10], [11], [12], [13], [14].

Pengolahan dan penggunaan kembali limbah cair greywater sangat membutuhkan data karakteristik dari limbah cair greywater khususnya data karakteristik berdasarkan sumber emisinya. Dengan mengetahui karakteristik dari sumber emisinya (karakteristik dari greywater yang berasal dari kamar mandi, dapur dan laundry) akan memberikan pengetahuan mendalam tentang kandungan polutan dan variasi karakter setiap sumber emisi. Pengetahuan karakter setiap sumber emisi ini, akan membantu dalam memperbaiki metode pengolahan limbah cair greywater.

Ketersediaan data karakteristik limbah cair greywater sangatlah minim bahkan nyaris tidak ada di Provinsi Lampung. Permasalahan serupa juga terjadi di negara maju. Sebuah penelitian yang dilakukan di negara Yunani dilatarbelakangi karena kekurangan data yang menggambarkan karakterisasi limbah cair greywater [15]. Padahal untuk mengurangi dampak buruk dari limbah ini, pengolahan limbah greywater harus diketahui terlebih dahulu berapa saja rata-rata kandungan polutan pada suatu wilayah. Karakteristik dari limbah greywater memang tidak ada yang pasti karena akan sangat dipengaruhi oleh aktivitas, berapa banyak penggunaan air dan juga iklim atau cuaca yang ada di suatu negara. Karena ketidakpastian inilah sudah seharusnya suatu negara memiliki database karakter limbah cair greywater ini agar pengolahannya tepat. Penelitian yang dilakukan di Yunani ini memfokuskan penelitiannya pada karakterisasi limbah cair greywater dengan parameter yang ditinjau: Biological Oxygen Demand (BOD), Chemical Oxygen Demand (COD), Total Suspended Solid (TSS), Total Dissoved Solid (TDS), kandungan Amonnia $\left(\mathrm{NH}_{4}\right)$, kandungan pospat $\left(\mathrm{PO}_{4}\right)$ dan konduktivitas dari limbah cair greywater. Penelitian ini juga melakukan pengolahan limbah cair berdasarkan karakteristik yang didapatkan sebelumnya yaitu menggunakan metode koagulasi, filtrasi dan adsopsi dan melihat peluang dari kemungkinan penggunaan kembali limbah cair greywater [15].

Selain itu, sebuah penelitian yang dilakukan di Hungaria, juga dilatarbelakangi karena tidak adanya database tentang karakter dari limbah cair greywater pada negara tersebut. Adapun parameter yang ditinjau pada penelitiannya meliputi: tingkat keasaman limbah $(\mathrm{pH})$, konduktivitas, TDS, Total Solid (TS), TSS, Turbiditas, Alkalinitas, BOD, COD, MBAS (deterjen). Sampel yang diambil sebanyak 96 rumah tangga dengan memperhatikan pola hidup dengan mengumpulkan data sosial ekonomi meliputi jenis kelamin, usia. Data sosial ekonomi sangat membantu dalam perkiraan produksi limbah cair greywater [16].

Di Indonesia sendiri penelitian tentang karakteristik limbah cair greywater masih sangat minim. Sebuah penelitian di wilayah Tangerang tentang karakteristik greywater dengan ruang lingkup yang sangat minim yaitu pada perumahan elit dan juga hanya mengambil sampel sebanyak 10 titik, dan pengambilan sampel sangat sederhana, yaitu hanya mengambil pada outlet saluran pembuangan sehingga mengabaikan untuk mengetahui berapa karakteristik greywater di setiap sumber limbah greywater [17].

Artinya berdasarkan penelitian terdahulu, database karakteristik greywater ini sangat penting, namun penelitian tentang karakteristik greywater ini masih minim terutama karakteristik berdasarkan emisinya. Untuk itulah penelitian ini dilakukan. Kelebihan dari penelitian yang dijalankan adalah parameter limbah greywater diukur berdasarkan sumber emisinya yaitu dari kamar mandi, dari dapur dan juga dari laundry. Tidak hanya itu, penelitian ini juga mempertimbangakan karakteristik limbah dari campuran ketiga sumber greywater dengan melakukan pencampuran menggunakan perbandingan limbah kamar mandi, dapur dan laundry $1,0: 0,5: 1,0$. Dimana penelitian tentang ini belum pernah ada yang melakukan sebelumnya.

Dalam penelitian ini, dilakukan karakterisasi limbah cair greywater dengan mengambil 12 sampel pada suatu rumah tangga dimana sampelsampel ini merupakan sampel dari tiga kali pengambilan sampel. Sampel limbah rumah tangga yang diambil berasal dari sebuah rumah tangga yang berada di Jalan Dulhadi gang 86-02 No. 2 Kebun Bibit, Kelurahan Hajimena, Kabupaten Lampung Selatan, Provinsi Lampung. Penelitian ini juga dilengkapi dengan pengumpulan data sosial ekonomi rumah tangga yang diambil sampel limbahnya. Metodologi pengambilan sampel data sosial ekonomi dilakukan dengan cara interview.

Penelitian ini bertujuan untuk melakukan karakterisasi limbah cair greywater berdasarkan sumber emisinya dengan parameter yang dilihat adalah BOD, COD, TSS, DO, temperature, $\mathrm{pH}$ dan turbiditas dari masing-masing sumber limbah cair 
greywater dan juga kondisi limbah yang sudah tercampur dari ketiga sumber limbah.

\section{METODOLOGI}

\section{Pengambilan Sampel Limbah Greywater}

Untuk mengevaluasi karakteristik limbah cair greywater berdasarkan emisinya (limbah dari dapur, laundry dan kamar mandi) sampel limbah diambil dari rumah sebuah rumah tangga yang berada di Jalan Dulhadi gang 86-02 No. 2 Kebun Bibit, Kelurahan Hajimena, Kabupaten Lampung Selatan, Provinsi Lampung. Lokasi penelitian dapat dilihat pada Gambar 1., dimana lokasi pengambilan sampel terlihat sebagai titik biru.

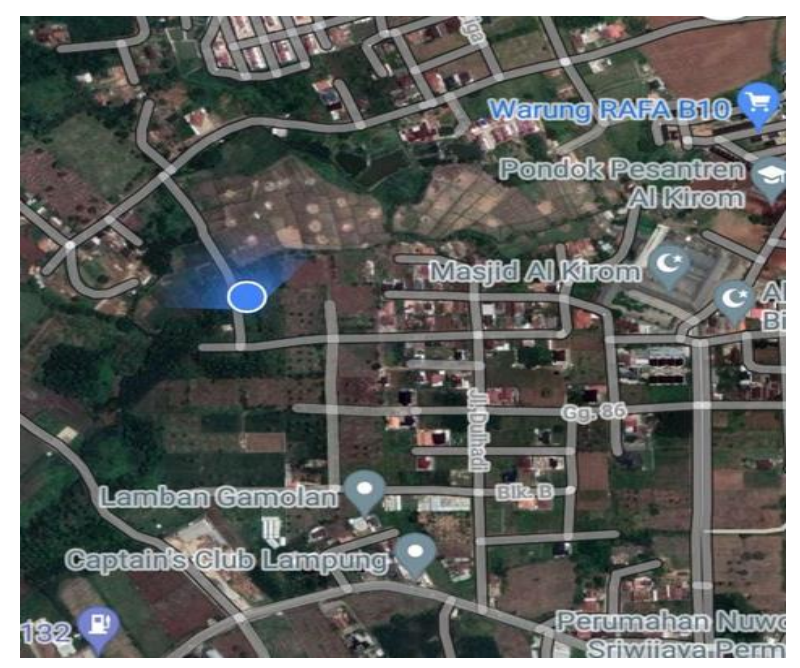

Gambar 1. Lokasi Penelitian

Proses pengambilan sampel limbah greywater dari dapur, laundry dan kamar mandi dilakukan dengan cara menampung limbah greywater tersebut di bak penampung (misalnya di ember) sebelum masing-masing limbah tersebut masuk ke dalam sistem pembuangan air limbah greywater. Limbah greywater perlu ditampung terlebih dahulu di bak penampung dikarenakan sistem pembuangan di lokasi penelitian adalah sistem pembuangan gabungan. Jadi tidak ada pemisahan antara pembuangan untuk limbah dari dapur, kamar mandi dan laundry. Dengan demikian, jika pengambilan sampel dilakukan dari outlet sistem pembuangan akan menyebabkan tidak memungkinkan untuk mendapatkan sampel yang berasal dari masing-masing sumber emisi limbah greywater. Setelah masing-masing limbah tertampung, kemudian sampel bisa dimasukkan ke dalam botol sampel.

Sebagai contoh, untuk pengambilan sampel limbah dari aktivitas dapur, air cucian piring dan atau air cucian bahan masakan (sayur, ikan, dll.) tidak langsung dibuang ke pembuangan air, tetapi ditampung di bak penampung (ember) selama proses aktivitas dapur berjalan sampai dengan aktivitas selesai. Hal serupa juga dilakukan untuk mendapatkan sampel dari kamar mandi, dan laundry. Selanjutnya sampel yang telah tertampung di bak penampung dari masing-masing sumber limbah greywater dimasukkan ke botol sampel. Pengambilan sampel dapat dilihat pada Gambar 2.

Di dalam penelitian ini, jumlah total sampel adalah sebanyak 12 (dua belas) buah, dimana sampel ini berasal dari tiga kali pengambilan, yaitu pengambilan pada tanggal 11 Juni 2021, 14 Juni 2021 dan 17 Juni 2021. Di setiap pengambilan sampel tersebut, 4 (empat) sampel diambil dengan rincian: sampel yang berasal dari limbah kamar mandi (M), dapur (D), laundry (L) dan sampel campuran (Mix) dengan perbandingan, limbah kamar mandi : limbah dapur : limbah laundry sebanyak 1 : 0.5 : 1 . Sampel limbah campuran ini sebagai upaya untuk mendekati kenyataan di lapangan bahwa semua limbah greywater di pembuangan pada dasarnya tercampur di sistem pembuangan. Semua sampel kemudian dikirim ke Laboratorium Succofindo untuk pegujian kualitas air yang meliputi karakteristik BOD, COD, TSS, DO, temperature, $\mathrm{pH}$ dan turbiditas.

Nama sampel diberikan index urutan per tanggal pengambilan. Pengambilan sampel pada tanggal 11 Juni 2021, sampel diberi penamaan M1 untuk sampel limbah kamar mandi pengambilan hari pertama, D1 adalah penamaaan untuk limbah dapur pada pengambilan sampel hari pertama, L1 adalah penamaan limbah laundry pada pengambilan hari pertama dan Mix1 adalah penamaan untuk limbah campuran pada pengambilan hari pertama. Demikian seterusnya untuk penamaan sampel pada hari berikutnya. Pengambilan sampel di tanggal 14 Juni 2021 diberikan nama sampel sebagai M2, D2, L2 dan Mix2. Terakhir Pengambilan ketiga, pada tanggal 17 Juni 2021, penamaan sampel adalah M3, D3, L3 dan Mix3. Sampel dapat dilihat pada Gambar 3 sampai dengan Gambar 5.

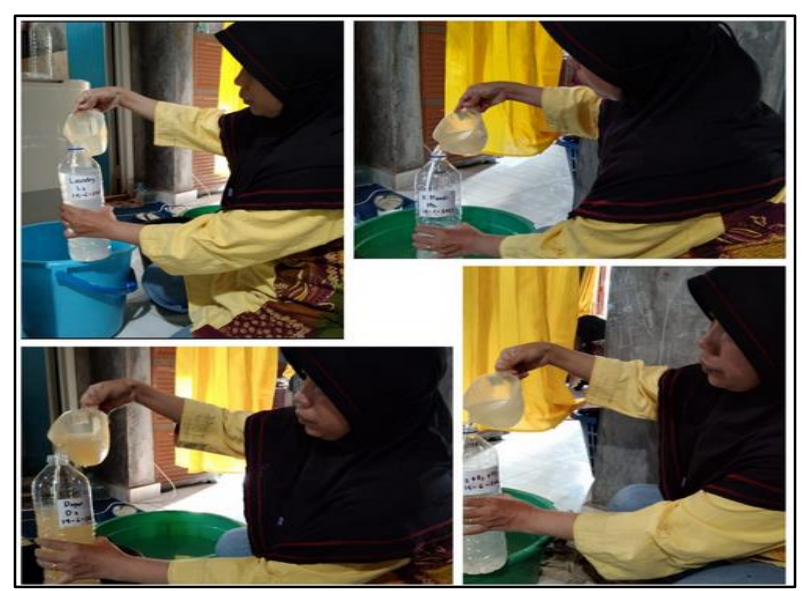

Gambar 2. Pengambilan Sampel

\section{Interview Kondisi Sosial Ekonomi Rumah Tangga}

Interview dilakukan untuk mengetahui kondisi sosial ekonomi rumah tangga dimana sampel limbah greywater diambil. Ada pun data sosial ekonomi yang digali adalah kelas ekonomi rumah tangga, jumlah anggota keluarga yang ada di 
dalam rumah tangga tempat sampel diambil. Kondisi sosial ekonomi ini akan mempengaruhi aktivitas rumah tangga dan juga limbah yang dihasilkan dari aktivitas rumah tangga.

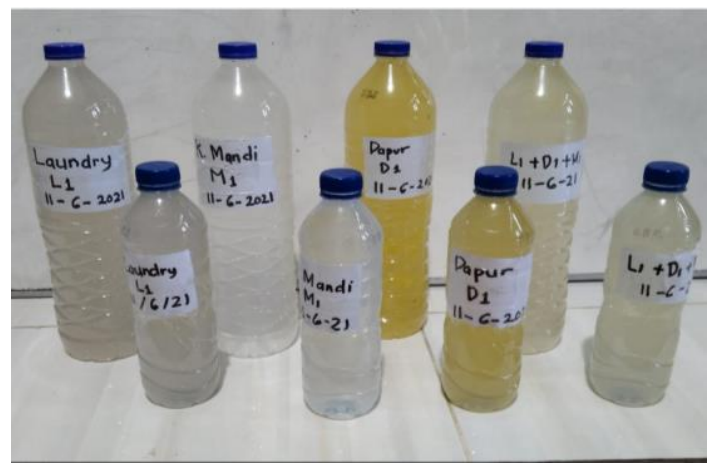

Gambar 3. Sampel M1, D1, L1 dan Mix1

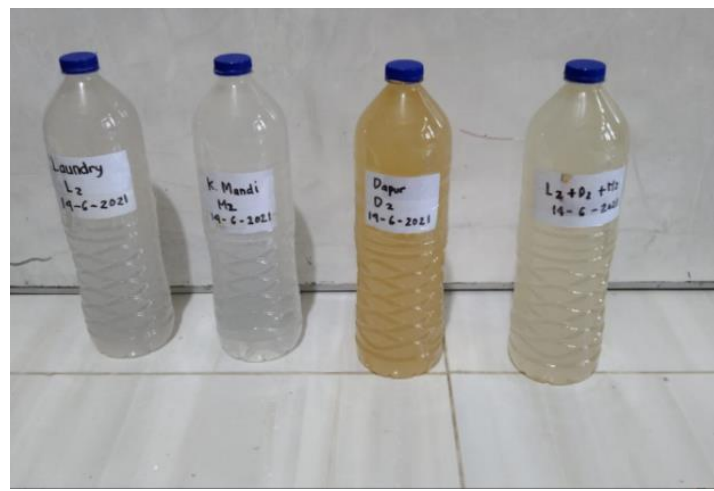

Gambar 4. Sampel M2, D2, L2 dan Mix2

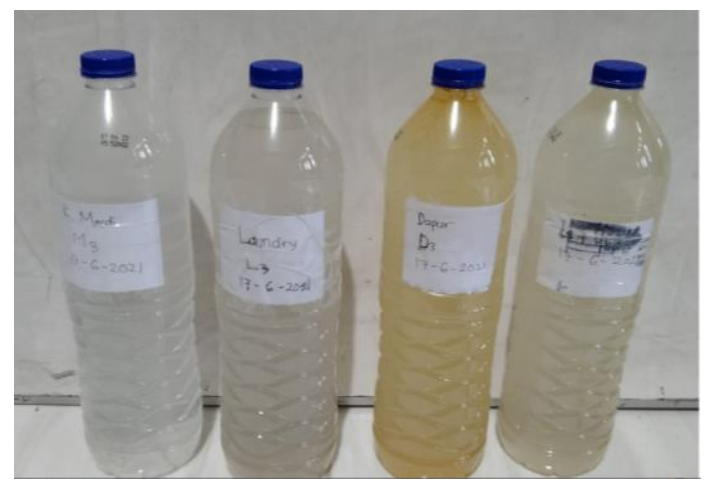

Gambar 5. Sampel M3, D3, L3 dan Mix3

\section{HASIL DAN DISKUSI}

\section{Hasil Uji Kualitas Air Limbah}

Dua belas sampel diambil untuk mengidentifikasi karakteristik greywater berdasarkan sumber emisinya. Karakteristik greywater yang menjadi fokus adalah BOD, COD, TSS, DO, temperature, $\mathrm{pH}$ dan turbiditas.

\section{Biochemical Oxygen Demand (BOD), Chemical Oxygen Demand (COD)}

Biochemical Oxygen Demand (BOD) menunjukkan jumlah oksigen terlarut yang dibutuhkan oleh organisme untuk melakukan proses degradasi terhadap bahan-bahan pencemar yang ada di dalam air. Nilai BOD yang tinggi mengindikasikan pencemaran pada air yang tinggi. Chemical Oxygen Demand (COD) adalah jumlah oksigen yang dibutuhkan agar bahan-bahan pencemar dapat terurai secara kimia. Perbandingan antara nilai BOD dan COD menjadi indikator apakah polutan termasuk kategori bioderadable atau tidak. Nilai BOD, COD dari hasil penelitian ini dapat dilihat pada Gambar 6 dan Gambar 7.

Berdasarkan Gambar 6 dan Gambar 7., dapat diketahui bahwa kandungan tertinggi BOD dan COD adalah dari limbah cair greywater dapur dengan kisaran 250-1000 mg/L untuk BOD dan 840-3430 $\mathrm{mg} / \mathrm{L}$ untuk COD. Hal ini sesuai dengan perkiraan karena beban polutan dari dapur jauh lebih tinggi jika dibandingkan pada limbah greywater yang berasal dari aktivitas mandi maupun cuci baju (laundry). Hasil penelitian ini selaras dengan hasil penelitian yang dilakukan di Yunani [16]. Hasil penelitian yang dilakukan di Yunani menunjukkan bahwa COD kamar mandi jauh lebih rendah dari COD dapur dengan nilai rerata COD kamar mandi sebesar $299 \mathrm{mg} / \mathrm{L}$ sedangkan COD dapur rerata menunjukkan nilai $775 \mathrm{mg} / \mathrm{L}$.

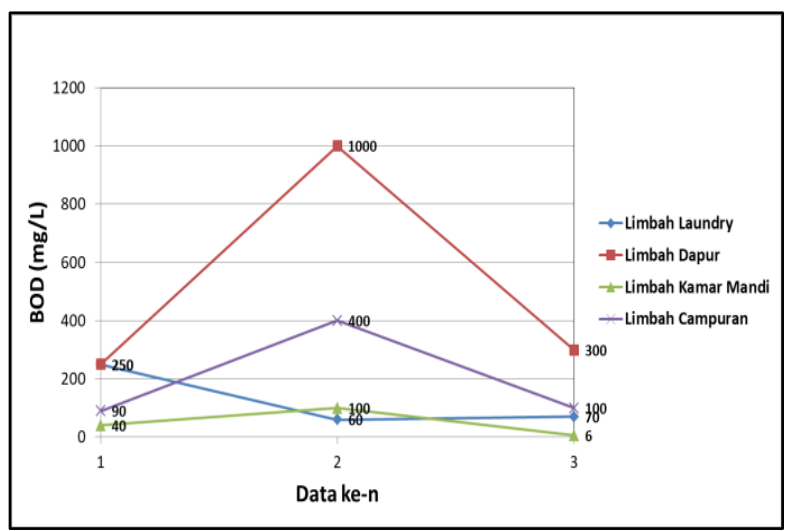

Gambar 6. Biochemical Oxygen Demand (BOD)

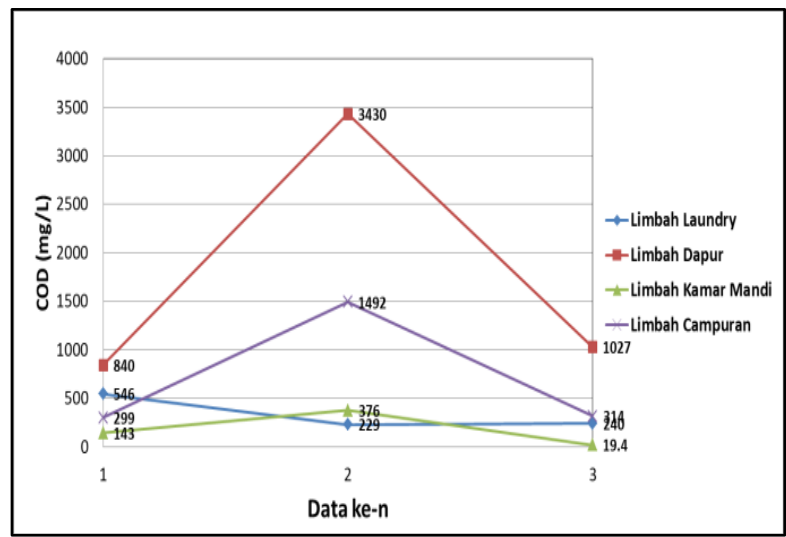

Gambar 7. Chemical Oxygen Demand (COD)

Limbah cair greywater dari hasil cucian baju menunjukkan nilai BOD berkisar 60-250 mg/L sedangkan nilai COD berkisar 229-546 mg/L. Kandungan BOD dan COD limbah greywater terendah berasal dari limbah kamar mandi dengan kandungan BOD 6-100 mg/L (Nilai ini hampir mirip dengan karateristik greyawter di Inggris dengan 
kisaran 90-185 mg/L [4]) sedangkan kandungan COD 19,4-143 mg/L. Kandungan BOD dan COD untuk limbah campuran ternyata memiliki kandungan BOD 90-400 mg/L.

Dengan kandungan BOD dan COD yang rendah, maka limbah cair greywater dari kamar mandi bisa menjadi sumber yang potensial sebagai alternatif sumber air baru, karena kadar polutannya yang rendah. Tentunya dengan kadar polutan yang rendah proses pengolahan limbahnya pun akan cenderung lebih mudah dan biaya yang dikeluarkan akan lebih murah.

Berdasarkan informasi dari Gambar 6 dan Gambar 7. ini dapat diambil kesimpulan selayaknya dilakukan pemisahan dalam proses pengumpulan limbah greywater ini untuk diolah dan digunakan kembali karena jika dibandingkan nilai BOD dan COD sampel campuran yang menjadi tinggi yaitu berkisar 90-400 mg/L untuk kandungan BOD dan 219-1492 mg/L untuk BOD.

Keseluruhan sampel baik sampel bukan campuran atau pun campuran menunjukkan rasio BOD/COD diantara 0,2-0,5 yang artinya sampel ini masuk kategori biodegradable. Nilai rasio BOD/COD ini tidak jauh berbeda dari karakteristik greywater di Negara Inggris dengan rentang 0,3 - 0,5 [4]. Jika rasio sampel kurang dari 0,1 maka sampel masuk kategori non-biodegradable. Maka limbah greywater ini cocok untuk dilakukan pengolahan secara biologis.

\section{Kadar pH}

Kadar pH dari hasil penelitian dapat dilihat pada Gambar 8. Dari empat kategori sampel dapat terlihat bahwa sampel yang berasal dari dapur memiliki tingkat keasaman yang relatif tinggi $(4,2-$ 5,7 ). Temuan hasil penelitian ini selaras dengan hasil penelitian sebelumnya yang menunjukkan bahwa kadar pH dapur lebih rendah (lebih asam) dari limbah kamar mandi [15][16]. Nilai pH dapur ini jika mengacu pada Keputusan Menteri Negara Lingkungan Hidup No. 112 Tahun 2003 tentang Baku Mutu (BM) Air Limbah Domestik, tidak memenuhi syarat baku mutu yang mensyaratkan pH dengan rentang 6-9. Pada dasarnya $\mathrm{pH}$ berkaitan erat dengan karbondioksida dan alkalinitas. Pada $\mathrm{pH}<5$, alkalinitas dapat mencapai 0 . Semakin tinggi $\mathrm{pH}$, semakin tinggi pula nilai alkalinitas dan semakin rendah karbondioksida bebas. Larutan yang bersifat asam ( $\mathrm{pH}$ rendah) bersifat korosif.

Sementara sampel dari laundry memiliki nilai pH antara 6-6,5 dikarenakan adanya keberadaan material bersifat alkali yang digunakan pada deterjen. Nilai $\mathrm{pH}$ limbah greywater dari aktivitas kamar mandi tidak jauh berbeda dengan nilai $\mathrm{pH}$ Laundry, yaitu berkisar antara 5,4-6,1. Sedangkan pada sampel campuran $\mathrm{pH}$ berkisar antara 5,1-5,9 dan ini menunjukkan $\mathrm{pH}$ sampel campuran juga tidak memenuhi baku mutu yang mengacu pada peraturan Kementrian Lingkungan Hidup tahun 2003.

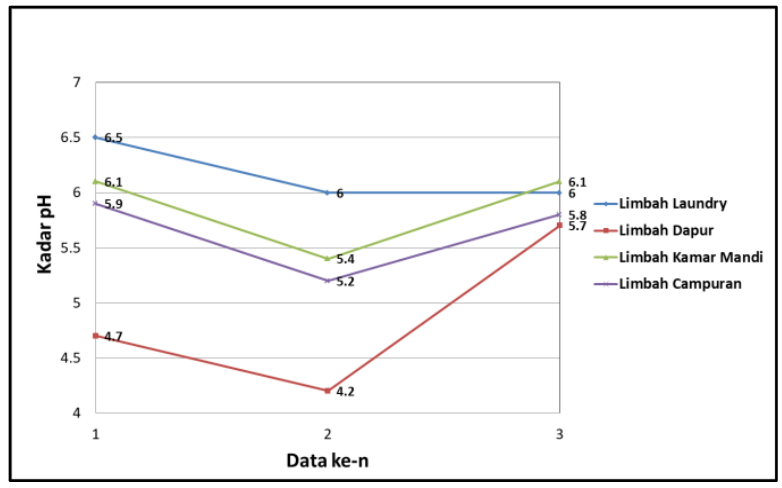

Gambar 8. Kadar pH

\section{Total Suspended Solids (TSS)}

Total Suspended Solids (TSS) atau total padatan tersuspensi adalah padatan yang tersuspensi di dalam air berupa bahan organik dan inorganik yang dapat disaring oleh kertas berpori $0,45 \mu \mathrm{m}$. Tingginya nilai TSS mengindikasikan buruknya kualitas air.

Nilai TSS dalam penelitian ini (Gambar 9.) juga memiliki trend yang sama seperti kandungan BOD dan COD, dimana nilai tertinggi masih berasal dari limbah greywater dapur (trend yang sama juga ditunjukkan pada karakteristik greywater di Yunani [15]). Nilai TSS dapur berkisar dari 202-620 mg/L. Nilai TSS dari karakteristik greywater di Yunani menunjukkan nilai rerata TSS sebesar $299 \mathrm{mg} / \mathrm{L}$ [15]. Untuk limbah kamar mandi dan laundry, nilai TSS hampir menunjukkan kisaran yang sama. Untuk TSS greywater laundry bernilai $31-96 \mathrm{mg} / \mathrm{L}$ sedangkan TSS greywater kamar mandi berkisar 34-85 mg/L.

Pada sampel campuran, nilai TSS maksimal terjadi pada sampel kedua bernilai $220 \mathrm{mg} / \mathrm{L}$ dengan nilai terkecil terjadi pada sampel kesatu, yaitu $57 \mathrm{mg} / \mathrm{L}$. Pada baku mutu air limbah domestic mensyaratkan TSS 100 mg/L. Berdasarkan hasil uji menunjukkan bahwa limbah greywater dapur dan campuran melebihi baku mutu yang disyaratkan.

\section{Turbiditas}

Turbiditas atau kekeruhan digunakan sebagai parameter derajat kegelapan dalam air yang disebabkan oleh material-material tersuspensi. Dari hasil uji kualitas air, kadar turbiditas dari dapur menunjukkan nilai tertingga jika dibandingkan data dari hasil uji turbiditas limbah laundry dan kamar mandi. Nilai turbiditas dari limbah dapur berkisar antara 92,5-168,5 NTU. Nilai ini lebih kecil jika dibandingkan dengan nilai TSS greywater di Yunani yang memiliki nilai rerata 357,39 $\pm 216,447$ NTU [15].

Trend nilai turbiditas (dapat dilihat pada Gambar 10.) juga hampir mirip dengan TSS, dimana nilai turbidats laundry dan kamar mandi hampir memiliki kisaran nilai yang sama. Untuk kamar 
mandi nilai turbiditas berkisar 24,1-40,7 NTU (Nilai TSS ini hampir sama dengan karakteristik di Negara Yunani yang memiliki rerata 25,45 NTU dengan standar deviasi 22,68 [15]) sedangkan nilai turbiditas laundry sebesar 35-96 NTU.

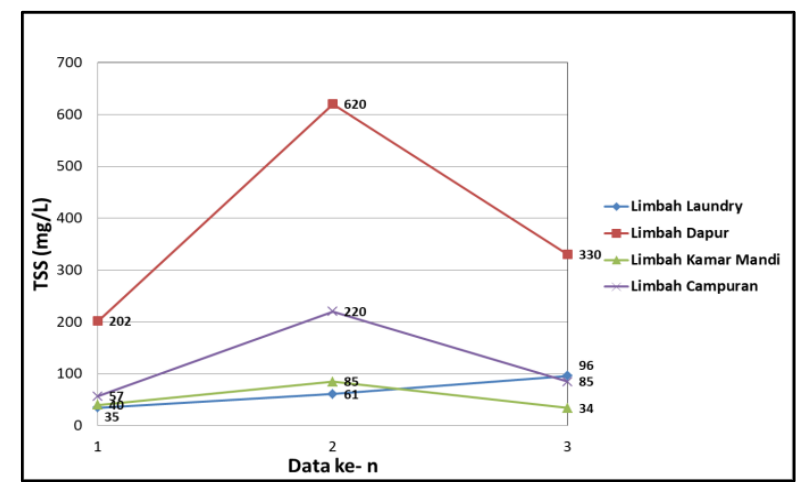

Gambar 9. Total Suspended Solids (TSS)

Pada sampel campuran, turbiditas tertinggi pada sampel Mix2 dengan nilai 220 NTU, sedangkan nilai terkecil pada sampel Mix 1 dengan nilai turbiditas 57 NTU.

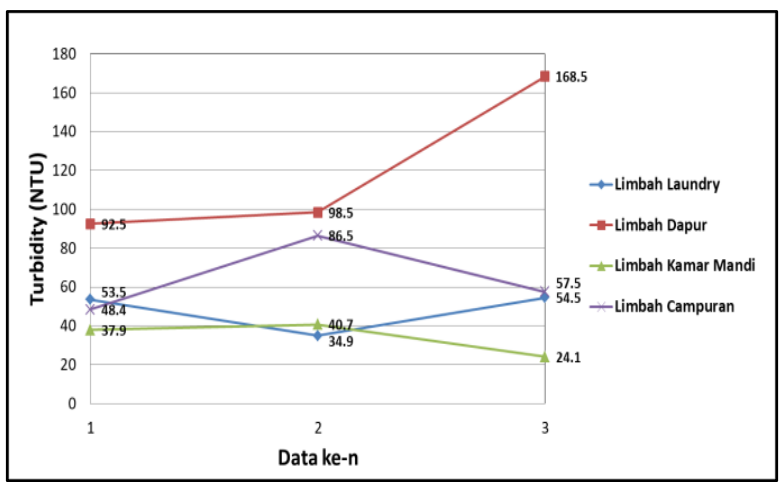

Gambar 10. Turbiditas

\section{Dissolved oxygen (DO)}

Dissolved oxygen (DO) adalah karakteristik limbah cair yang menunjukkan berapa besar kandungan oksigen terlarut di dalam air. Kandungan oksigen terlarut ini penting untuk organisme yang ada di air untuk dapat hidup. Nilai DO dibawah $3 \mathrm{mg} / \mathrm{L}$ dalam sebuah badan air merupakan titik kritis bagi organisme untuk hidup. Dengan kondisi DO di bawah $1 \mathrm{mg} / \mathrm{L}$ disebut kondisi hypoxic (level oksigen yang rendah)

Berdasarkan hasil penelitian, nilai DO (dapat dilihat pada Gambar 11.) secara keseluruhan menunjukkan nilai yang variatif. Untuk limbah greywater yang bersumber dari limbah laundry nilai DO berkisar antara 1,2-2 mg/L. Pada limbah greywater dapur, nilai DO berada pada kisaran 1,09-2,16 mg/L. Sedangkan pada limbah greywater yang berasal dari aktivitas kamar mandi DO bernilai 0,99-2,68 mg/L. Pada sampel yang merupakan campuran ketiga sumber greywater, nilai DO antara 0,63-2,26 mg/L. Dari hasil penelitian ini menunjukkan bahwa keseluruhan sampel memiliki kadar oksigen terlarut yang rendah.

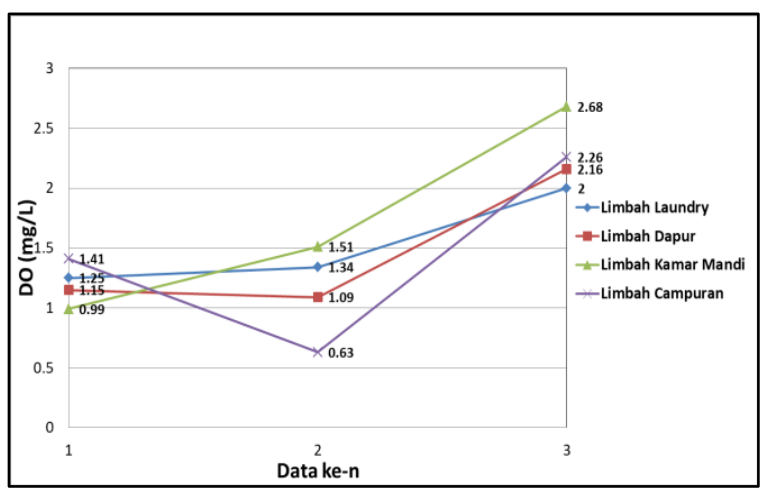

Gambar 11. Dissolved oxygen (DO)

Untuk melihat hubungan antara parameter TSS, turbidity dan kelarutan oksigen (DO), ditampilkan pada Gambar 12 sampai dengan Gambar 15. Pada umumnya, nilai padatan terlarut akan berbanding lurus dengan nilai kekeruhan dan berbanding terbalik dengan kelarutan oksigen.

Di dalam penelitian ini ditemukan sesuatu yang tidak sinkron pada sampel dapur ke-2 dan ke3. Pada sampel ke- 2 TSS berada di angka tertinggi yaitu $620 \mathrm{mg} / \mathrm{L}$ dengan turbiditas 98,5 NTU namun pada sampel ke-3 nilai TSS turun cukup signifikan ke angka $350 \mathrm{mg} / \mathrm{L}$ dengan turbiditas yang naik cukup signifikan ke angka 168,5 NTU.

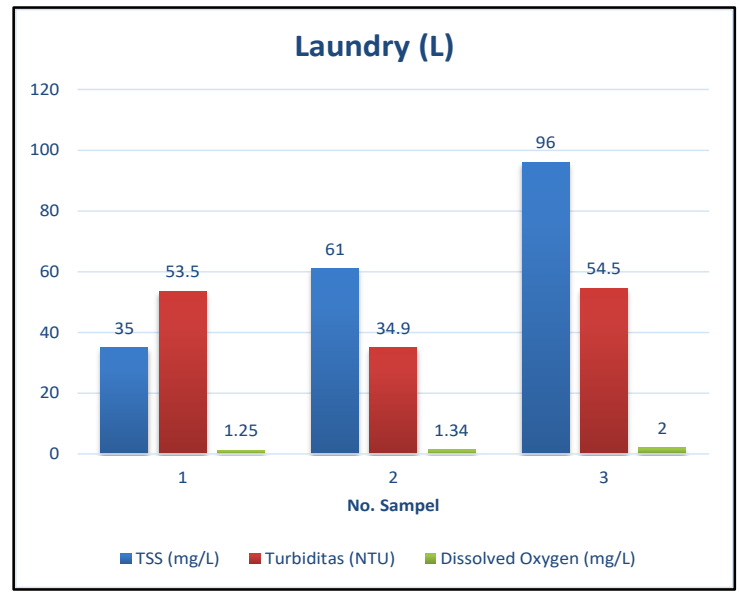

Gambar 12. Hubungan TSS, Turbiditas dan DO pada Limbah greywater Laundry

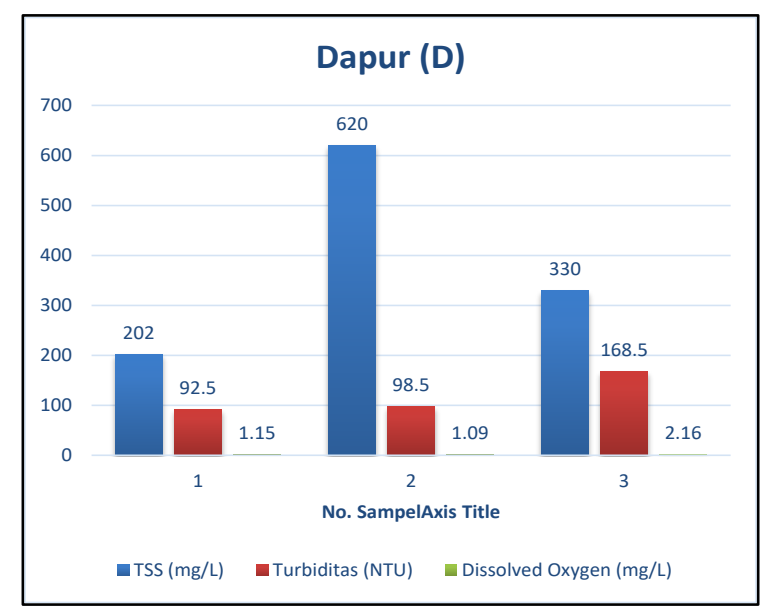

Gambar 13. Hubungan TSS, Turbiditas dan DO pada Limbah greywater Dapur 


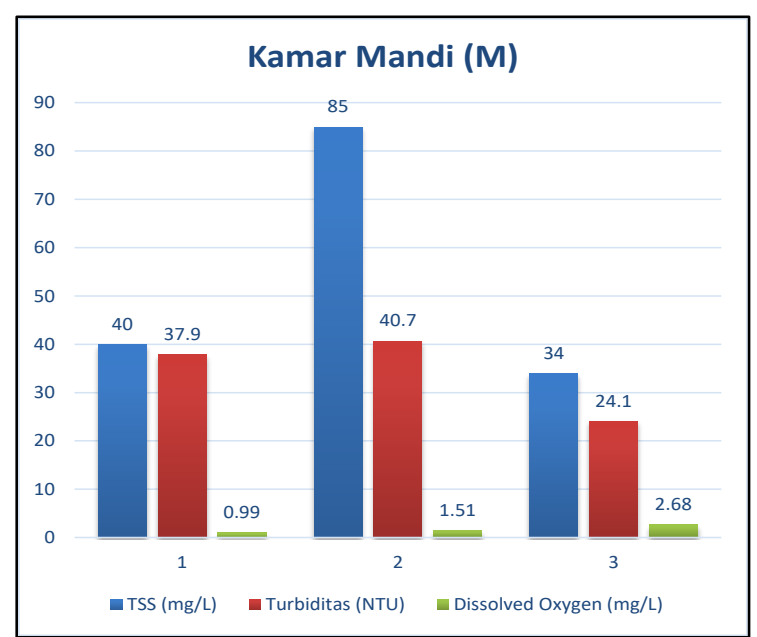

Gambar 14. Hubungan TSS, Turbiditas dan DO pada Limbah greywater Kamar Mandi

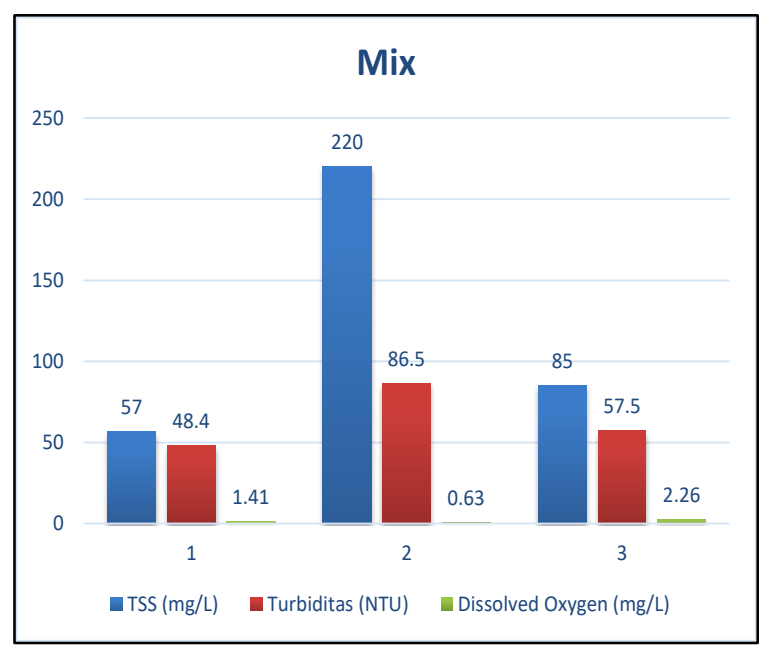

Gambar 15. Hubungan TSS, Turbiditas dan DO pada Limbah greywater Mix

\section{Suhu}

Untuk parameter suhu, berdasarkan hasil penelitian suhu sampel bervariasi. Keseluruhan sampel baik sampel sumber emisi maupun sampel campuran tidak memiliki perbedaan suhu yang jauh, dengan nilai kisaran suhu dari $22^{\circ} \mathrm{C}-24,5^{\circ} \mathrm{C}$.

\section{Kondisi Sosial Ekonomi Rumah Tangga Tempat Sampel diambil}

Rumah tangga yang diambil sampelnya memiliki anggota keluarga 4 (empat) orang, yang terdiri dari ayah, ibu dan 2 (dua) orang anak kecil usia 7 tahun dan 6 tahun. Pekerjaan kepala rumah tangga adalah wiraswasta dengan penghasilan ratarata Rp.10.000.000 (sepuluh juta rupiah sebulan) dengan kelas ekonomi menengah.

Sumber air bersih dari rumah tangga adalah sumur dangkal yang ada di rumah. Keseluruhan air limbah yang terbentuk merupakan hasil pemakaian dari air bersih yang bersumber dari air sumur dangkal ini. Sistem pembuangan air limbah greywater di rumah tangga ini adalah sistem gabungan (combined sewer system). Jadi air buangan tercampur antara air yang bersumber dari air dapur, air kamar mandi dan air laundry serta air hujan bercampur menjadi satu.

Data sosial ekonomi ini sangat penting, karena karakteristik greyawater sangat variatif karena dipengaruhi oleh kebiasaaan hidup, pendapatan rumah tangga, penggunaan produk dan penggunaan air. Rumah tangga dengan income tinggi memiliki kecendrungan pemakaian air lebih tinggi dan berbagai jenis produk pembersih rumah tangga. Rumah tangga dengan pendapatan rendah, kecendrungan memakai produk yang lebih murah, pemakaian air juga lebih sedikit. Komposisi greywater sangat erat hubungannya dengan volume produksinya. Ketika sedikit air yang digunakan maka akan memberikan kecondongan konsentrasi polutan yang tinggi.

\section{KESIMPULAN}

Berdasarkan hasil penelitian, maka dapat diambil kesimpulan keseluruhan sampel baik sampel yang merupakan sumber emisi maupun sampel campuran menunjukkan nilai rasio BOD/COD antara 0,2-0,5 yang artinya sampel adalah biodegradable. Dimana kandungan BOD dan COD tertinggi berasal dari dapur dengan 250-1000 $\mathrm{mg} / \mathrm{L}$ untuk BOD dan 840-3430 mg/L untuk COD. Sedangkan kandungan terendah berasal dari greywater aktivitas mandi dengan BOD 6-100 mg/L sedangkan kandungan COD 19,4-143 mg/L. Kandungan BOD dan COD sampel campuran berkisar $90-400 \mathrm{mg} / \mathrm{L}$ untuk kandungan BOD dan 219-1492 mg/L untuk BOD. Untuk parameter kadar $\mathrm{pH}$ dari keduabelas sampel berkisar dari 4,2-6,5. Untuk parameter kandungan TSS trend nilai masih tertinggi berasal dari dapur dengan nilai $202-620$ $\mathrm{mg} / \mathrm{L}$. TSS mix tertinggi bernilai $220 \mathrm{mg} / \mathrm{L}$. Begitu juga dengan nilai turbiditas atau kekeruhan, tertinggi terjadi pada limbah greywater Dapur. Kadar DO keseluruhan sampel memiliki kadar oksigen terlarut yang rendah yang ditunjukkan dari hasil penelitian bernilai kurang dari $3 \mathrm{mg} / \mathrm{L}$ bahkan ada yang kurang dari $1 \mathrm{mg} / \mathrm{L}$. Keseluruhan sampel tidak memiliki perbedaan suhu yang jauh, dengan nilai kisaran suhu dari $22^{\circ} \mathrm{C}-24,5^{\circ} \mathrm{C}$.

\section{UCAPAN TERIMA KASIH}

Kami ucapkan terimakasih kepada Lembaga Penelitian dan Pengabdian Masyarakat (LPPM) Universitas Lampung yang telah mendanai kegiatan penelitian ini. Tidak lupa pula kami sampaikan terima kasih kepada tim penelitian Fakultas Teknik Universitas Lampung atas bantuannya sehingga kegiatan penelitian ini berjalan dengan lancar.

\section{REFERENSI}

[1] E. Eriksson, K. Auffarth, M. Henze, and A. Ledin, "Characteristics of grey wastewater," Urban Water, vol. 4, no. 1, 2002, doi: 10.1016/S1462-0758(01)00064-4. 
[2] E. Friedler and M. Hadari, "Economic feasibility of on-site greywater reuse in multi-storey buildings," Desalination, vol. 190, no. 1-3, 2006, doi: 10.1016/j.desal.2005.10.007.

[3] E. Friedler, "Quality of individual domestic greywater streams and its implication for on-site treatment and reuse possibilities," Environ. Technol., vol. 25, no. 9, 2004, doi: 10.1080/09593330.2004.9619393.

[4] B. Jefferson, A. Palmer, P. Jeffrey, R. Stuetz, and S. Judd, "Grey water characterisation and its impact on the selection and operation of technologies for urban reuse," Water Sci. Technol., vol. 50, no. 2, 2004, doi: 10.2166/wst.2004.0113.

[5] F. Li, K. Wichmann, and R. Otterpohl, "Review of the technological approaches for grey water treatment and reuses," Science of the Total Environment, vol. 407, no. 11. 2009, doi: 10.1016/j.scitotenv.2009.02.004.

[6] E. Donner, E. Eriksson, D. M. Revitt, L. Scholes, H. C. H. Lützhøft, and A. Ledin, "Presence and fate of priority substances in domestic greywater treatment and reuse systems," Sci. Total Environ., vol. 408, no. 12, 2010, doi: 10.1016/j.scitotenv.2010.02.033.

[7] P. Soewondo and A. Yulianto, "THE EFFECT OF AERATION MODE ON SUBMERGED AEROBIC BIO FILTER REACTOR FOR GREY WATER TREATMENT," Environ. Eng., vol. 3, no. 3, 2008.

[8] Y. Gilboa and E. Friedler, "UV disinfection of RBC-treated light greywater effluent: Kinetics, survival and regrowth of selected microorganisms," Water Res., vol. 42, no. 45, 2008, doi: 10.1016/j.watres.2007.09.027.

[9] R. M. S. Radin Mohamed, A. A. S. Al-Gheethi, A. H. Mohd Kassim, A. Martin, S. Dallas, and M. H. Bin Khamidun, "A Potential Reuse of Greywater in Developed and Developing Countries," 2019.

[10] L. Domnech and D. Saurí, "Socio-technical transitions in water scarcity contexts: Public acceptance of greywater reuse technologies in the Metropolitan Area of Barcelona," Resour. Conserv. Recycl., vol. 55, no. 1, 2010, doi: 10.1016/j.resconrec.2010.07.001.
[11] C. Matos, A. Sampaio, and I. Bentes, "Possibilities of greywater reuse in nonpotable in situ urban applications, according with its quality and quantity," WSEAS Trans. Environ. Dev., vol. 6, no. 7, 2010.

[12] U. Pinto and B. L. Maheshwari, "Reuse of greywater for irrigation around homes in Australia: Understanding community views, issues and practices," Urban Water J., vol. 7, no. 2, 2010, doi: $10.1080 / 15730620903447639$.

[13] K. A. Mourad, J. C. Berndtsson, and R. Berndtsson, "Potential fresh water saving using greywater in toilet flushing in Syria," J. Environ. Manage., vol. 92, no. 10, 2011, doi: 10.1016/j.jenvman.2011.05.004.

[14] D. M. Revitt, E. Eriksson, and E. Donner, "The implications of household greywater treatment and reuse for municipal wastewater flows and micropollutant loads," Water Res., vol. 45, no. 4, 2011, doi: 10.1016/j.watres.2010.11.027.

[15] G. Antonopoulou, A. Kirkou, and A. S. Stasinakis, "Quantitative and qualitative greywater characterization in Greek households and investigation of their treatment using physicochemical methods," Sci. Total Environ., vol. 454-455, 2013, doi: 10.1016/j.scitotenv.2013.03.045.

[16] I. Bodnar, A. Szabolcsik, E. Baranyai, A. Uveges, and N. Boros, "Qualitative characterization of household greywater in the northern great plain region of Hungary," Environ. Eng. Manag. J., vol. 13, no. 11, 2014, doi: 10.30638/eemj.2014.302.

[17] A. E. South, E. Nazir., "KARAKTERISTIK AIR LIMBAH RUMAH TANGGA (grey water) PADA SALAH SATU PERUMAHAN MENENGAH KEATAS YANG BERADA DI Tangerang Selatan," Ecolab, vol. 10, no. 2, 47-102, 2016. 